could compile special reports : "The Board found that those who were still in their academic settings managed to find time for something within their com. petence which was directly concerned with the war. Once a scholar was in Washington it was hard to get much out of him, and once he got into uniform, however sedentary the assignment, it was almost impossible."

\section{Science and Society in Ancient China}

IN his Conway Memorial Lecture, "Science and Society in Ancient China", delivered on May 12, 1947, Dr. Joseph Needham attempts to sketch a pattern of the organisation of Chinese feudal society and its relation to Western European society (London : Watts and Co., Ltd. 2s. net). While the Taoist hermits who withdrew from human society to contemplate Nature had no scientific method, they tried to understand Nature in an intuitive and observa. tional way, and the earliest chemistry and astronomy in Asia had Taoist connexions. In ancient China, although Taoist empirical mysticism favoured the development of science, Confucian ethical rationalism was antagonistic, and it could not be claimed that all through history rationalism had been the chief progressive force in society. While inventions and technological discoveries such as gunpowder, paper, printing, the magnetic compass and efficient animal harness, which changed the course of civilization, were made in China, modern science and technology did not develop them. Dr. Needham points out that the status of military technology may deeply affect the crystallization of social philosophy, and that a moral question such as slavery may be closely connected with technical factors. Philosophical and ethical thought, he believes, can never be dissociated from their material basis, and he thinks that Chinese civilization was basically inhibited from giving rise to modern science and technology, because the society which grew up in China after the feudal period was unsuitable for these developments. Dr. Needham concludes by commending a closer study of the great classics of Chinese philosophy and of the parallel course of technology in China.

\section{Interchange of Technical Publications in Sheffield}

A REPORT on the progress made during the last year by the Organisation for the Interchange of Technical Publications in Sheffield was presented to the fifteenth annual general meeting held in the Central .Library, Sheffield, on December 2. This Organisation controls a system of co-operative borrowing of books, periodicals and other records, between the numerous special libraries in the Sheffield area. Recent activities of the Organisation have been directed to other ways of assisting research and development now that the effective pooling of technical publications and information has been operating for many years. The annual report shows that 1,459 publications were borrowed last year. A survey of the location of foreign patents in British libraries was undertaken; through the Association of Special Libraries and Information Bureaux, the Patents Office was asked to close the gap in indexes and abridgments to British patent specifications left during the War; and an inquiry made as to the amount of assistance obtainable from the Nederlandsch Instituut voor Documentatio en Registratuur in foreign patent searches. At the annual general meeting, it was decided to ask the Board of Trade to have the mass of documents relating to war-time
German industry held by the Technical Information and Documents Unit of the Board abstracted and indexed on similar lines to the work done in the United States by the Air Technical Intelligence and to have the more important items translated on the advice of technical experts. It was also recommended that files of the microfilms taken by the Board of machine drawings selected from this collection should be deposited with the leading technical libraries of Britain. Twenty-four firms and seven societies and institutions now belong to the Organisation.

\section{Textile Laboratories at Leeds}

THE International Wool Secretariat has for the past ten years given increasing support to the University of Leeds for research on wool ; it has now made a gift of $£ 10,000$ for the purchase of equipment for the new Textile Laboratories, all the apparatus to be utilized for the benefit of the wool industry. At present, five men hold Secretariat fellowships in the Department, and in addition, a grant of $£ 1,600$ a year has been made during the past two years in support of research in textile engineering. The number of workers engaged on these and other wool research projects is now so great that a severe strain has been thrown on the laboratory accommodation. In 1946, however, the Worshipful Company of Clothworkers of London made a grant of $£ 20,000$ towards the building of new wool research laboratories, and a start on the work was made in December 1947. The ground floor of the new building will be used to extend the Cloth Finishing Section of the Department, while the first floor will contain several laboratories for wool research workers. The second floor will take the form of one large laboratory, which will be used to give undergraduates practical experience of the applications of chemistry at all stages of the manufacture of wool textile materials. The grant of $£ 10,000$ from the International Wool Secretariat is for the equipment of the new building and will be used to purchase the most modern types of machinery for the Finishing Section, as well as the special apparatus which will be needed by research workers and undergraduates.

\section{Old Scientific and Natural History Books}

THE following catalogues have been issued by Messrs. Bernard Quaritch, Ltd., of 11 Grafton Street, London, W. : No. 644, Books and Periodicals relating to Mathematics, Physics and Allied Sciences including two small collections on Accountancy and Mining; No. 650, Books and Periodicals on all Branches of Zoology, Geology, Palæontology and Botany ; and a Catalogue of Books and Manuscripts issued to commemorate the One Hundredth Anniversary of the firm of Bernard Quaritch : 1847-1947. Noteworthy among these is Messrs. Quaritch's centenary catalogue. This is of especial interest to booklovers on account of the introductory matter, in which is related the growth of the firm from small beginnings in October 1847, in a shop in Castle Street, Leicester Square, London, to its present status as a business of world-wide repute. There is also a portrait of the founder, who died in 1899, and a brief sketch of his life, prepared by his daughter, Mrs. Charlotte Quaritch Wrentmore. As might have been anticipated, this catalogue is worthy of the occasion. It is a lavishly illustrated production, containing six coloured and some forty black-and. 